2017

\title{
Law and Digestion: A Brief History of an Unpalatable Idea
}

Dan Priel

Osgoode Hall Law School of York University, dpriel@osgoode.yorku.ca

Follow this and additional works at: https://digitalcommons.osgoode.yorku.ca/olsrps

Part of the Law Commons

\section{Recommended Citation}

Priel, Dan, "Law and Digestion: A Brief History of an Unpalatable Idea" (2017). Osgoode Legal Studies Research Paper Series. 194. https://digitalcommons.osgoode.yorku.ca/olsrps/194 


\title{
Law and Digestion: A Brief History of an Unpalatable Idea Dan Priel ${ }^{*}$
}

\begin{abstract}
According to a familiar adage the legal realists equated law with what the judge had for breakfast. As this is sometimes used to ridicule the realists, prominent defenders of legal realism have countered that none of the realists ever entertained any such idea. In this short essay I show that this is inaccurate. References to this idea are found in the work of Karl Llewellyn and Jerome Frank, as well as in the works of their contemporaries, both friends and foes. But I also show the idea is older than the legal realists. One finds casual references to it in academic literature and newspapers from around that time, which suggest that the phrase reflected something of a received, if cynical, wisdom. Although none of the realists ever studied the question seriously, I further explain how it fit within their views on law, as well as how it might be tested today.
\end{abstract}

Now I really do see that judges and governors ought to be and need to be made of bronze, so as not to be worn out by all the pestering from these folks who come on business and expect you to be listening to them and dealing with them at all hours of the day and night, and attending only to their affairs, come what may....So, all you fools and idiots coming on business: don't be in such a hurry, wait until the proper time, don't come when it's time for me to be eating or sleeping, because judges are made of flesh and blood, and must give to nature what nature naturally needs....

\section{I.}

The English judge Charles Bowen once said that "the state of a man's mind is as much a fact as the state of his digestion." ${ }^{2}$ As a statement on either the mind or digestion, it is probably not very controversial; the connection between the two, however, has proven more contentious. When Judge Alex Kozinski wanted to make fun of the legal realists, he attributed to them the view that law is what the judge had for breakfast. ${ }^{3}$ For him, this showed just how ridiculous some legal scholars' ideas could be, how unmoored from reality, perhaps even how irresponsible. But did

\footnotetext{
* Osgoode Hall Law School, York University. Thanks to Chad Flanders, Jack Schlegel, Max Weaver, and especially Simon Stern for their comments as well as for alerting me to some sources I overlooked. (This is a somewhat revised version of the one originally uploaded to SSRN. The main differences pertain to the information on Charlton Lewis, thanks to a discovery made by Simon Stern.)

${ }^{1}$ Miguel de Cervantes, Don Quixote 8I2 (Penguin, John Rutherford trans., 2000) (I6I5).

${ }^{2}$ Edgington v. Fitzmaurice, 29 Ch.D. 459, 483 (1885) (C.A. (Eng.)) (Bowen L.J.).

${ }^{3}$ Alex Kozinski, What I Had for Breakfast and Other Mysteries of Judicial Decision Making, 26 LoY. L.A. L. REv. 993, 993 (I993).
} 
any legal realist ever say this? In his sympathetic reconstruction of legal realism Brian Leiter denied the charge. ${ }^{4}$ Frederick Schauer has also failed to identify any clear source for the idea, suggesting instead that Jerome Frank only made this as an "offhand oral quip," or even that he was saddled by what was actually said "in jest" by other people. ${ }^{5}$ And yet the idea lives on, at times as a harmless exaggeration of the legal realists and their ideas, at others as the object of ridicule. Is there any truth to it, or is this just an urban legend? ${ }^{6}$

It should not surprise readers that the idea is more frequently found in the writings of the realists' critics. If there is one person responsible for the association of legal realism with judicial bowel movements, it is Walter Kennedy, who was a contemporary of many of the legal realists. A professor of law at Fordham, he was described as "perhaps the most widely respected Catholic legal scholar" in America of his generation, and a part of group of Catholic legal scholars who during the I930s and I940s attacked the legal realists for what they perceived as dangerous ideas. ${ }^{8}$ It was not uncommon for these critics to suggest that realist ideas were similar (and perhaps even led) to those of the European fascists. Kennedy was the most persistent of the group, writing over fifteen articles dedicating to realism bashing. ${ }^{9}$

For Kennedy, just as it was for Kozinski, the what-the-judge-had-for-breakfast trope served as a reductio, proof of how ridiculous the legal realists were. He made repeated references to it, mocking the realists for their suggestion that lawyers should become "stomach specialists,"10 that they believed "gastronomical disturbances"11 affected the outcomes of cases, that they thought

\footnotetext{
${ }^{4}$ See Brian Leiter, Naturalizing Jurisprudence: Essays on American Legal Realism and Naturalism IN Legal Philosophy 62 (2007).

${ }^{5}$ Frederick Schauer, Thinking Like a Lawyer: A New Introduction to Legal Reasoning i29 n.i5 (2009). A recent note on the European history of this idea similarly stated that it was "unclear whether any of the American realists really claimed anything of that sort." Giovanni Tuzet, A Short Note on Digestive Realism, 25 REVUS II, II (2015).

${ }^{6}$ For a recent example, showing the idea lives beyond academia, and that its association with legal realism has crossed the Atlantic see David Pannick, Why No Offender Wants to Face a Judge Who Is Tired, Hungry or Disappointed, TIMES (London), (Jan. I9, 20I7), available at http://www.thetimes.co.uk/article/why-no-offenderwants-to-face-a-judge-who-is-tired-hungry-or-disappointed-6bdxbm2wo.

${ }^{7}$ Edward A. Purcell, Jr., The Crisis of Democratic Theory: Scientific Naturalism \& the Problem OF VALUE I65 (1973).

${ }^{8}$ The most extensive discussion of the Catholic critique of legal realism is John M. Breen \& Lee J. Strang, The Forgotten Jurisprudential Debate: Catholic Legal Thought's Response to Legal Realism, 98 MARQ. L. REV. I203 (2015). They list fourteen Catholic scholars who wrote critically of legal realism. See id. at I258 n.4I6.

${ }^{9}$ See $i d$. at $\mathbf{I} 230$ n.200, for a list of seventeen essays containing a substantial critique of legal realism. Even this list is incomplete as it does not include critical reviews, such as the one cited in note 13 , infra.

${ }^{10}$ Walter B. Kennedy, Another Job for Jurisprudence, 8 MOD. L. REV. I8, 2 I (I945).

${ }^{11}$ Walter B. Kennedy, Law Reviews as Usual, I2 Fordham L. Rev. 50, 55 (1943); Walter B. Kennedy, $A$ Review of Legal Realism, 9 FORDHAM L. REV. 362, 366 (1940) (attributing to the legal realists "the gastronomical approach which urges the advocate to take a sly glance at the judge's breakfast menu").
} 
lawyers should not bother with "dust-laden volumes" but investigate "how [the judge or legistor's] digestive tract is functioning." ${ }^{12}$ In one place he referred to it as the "so-called "wheatieexplanation" of judicial opinions. ${ }^{13}$

But it is not just critics who attributed the idea to the legal realists and focused on it as a kind of synecdoche for their entire oeuvre. In a speech delivered in I94I, Judge Charles Clark told his audience that "the legal realists have acquired the name —or frame-of the 'gastronomical school of jurisprudence,' since they are supposed to attribute judicial opinion primarily to what the judge had for breakfast." ${ }^{14}$ Unlike Kennedy, Clark was sympathetic to the realist cause. Before his appointment to the bench Clark had served as dean of Yale Law School where many of the culprits were based, and he made it clear that thought they had an important message. ${ }^{15}$

II.

These early attributions only make the question of origins even more intriguing. Is this a myth with no basis in reality? As far as I could find, the first appearance of something like this idea in the work of an American academic is in a 1905 essay by Roscoe Pound. He wrote there that judges should not be like "the oriental cadi administering justice at the city gate by the light of nature tempered by the state of his digestion for the time being." ${ }^{\prime 6}$

Whether Pound belongs in the ranks of the legal realists is a topic best left for another place ${ }^{17}$ Be that as it may, Pound used the idea, perhaps facetiously, as a contrast to his ideal of principled adjudication, quite the opposite of the supposed realist view. And in any event, neither Kennedy nor Clark mentioned Pound in their essays. Clark, in fact, did not cite anyone in relation to this idea; but Kennedy did. His source was an article by Karl Llewellyn, entitled On Reading and Using the Newer Jurisprudence. ${ }^{18}$ The essay was a critical survey of ideas that had been percolating in the legal academy in the previous decade. Its main goal was to show that the questions

${ }^{12}$ Walter B. Kennedy, Men or Laws, 2 BroOK. L. ReV. II, I3 (1932).

${ }^{13}$ Walter B. Kennedy, Book Review, 89 U. PA. L. ReV. 995, 996 (I94I) (reviewing EdwiN N. Garlan, Legal ReALism AND JustiCe (I94I)). So called by whom? I have not been able to find any other reference to this expression. Perhaps it was more widely used in law school corridors of the day, leaving this lone written reference as the sole remaining remain ossified in print for the legal paleontologists to observe.

${ }^{14}$ Charles E. Clark, The Function of Law in a Democratic Society, 9 U. CHI. L. REV. 393, 394 (I94I).

${ }^{15}$ See id. at 395 .

${ }^{16}$ Roscoe Pound, The Decadence of Equity, 5 Colum. L. ReV. 20, 2 I (I905). This passage is quoted in Jerome Frank, Are Judges Human? Part One: The Effects on Legal Thinking of the Assumption that Judges Behave Like Human Beings, 80 U. PA. L. Rev. I7, 24 n.I7 (193I). Frank, however, criticized Pound for his legal orientalism. See id. at $24-25$.

${ }^{17}$ On the realists' complicated relationship with Pound (and vice versa) see N.E.H. Hull, Roscoe Pound AND Karl LleWELLYN: SEARCHING FOR AN AMERICAN JURISPRUdENCE (I997).

${ }^{18}$ The article was published in two parts in 26 A.B.A. J. 300, 4I 8 (1940) and in one part in 40 COLUM. L. REV. 58I (1940). All further citations are to the Columbia Law Review version. 
and problems "jurisprudes" were discussing at the time were relevant and useful even for the most practically-oriented lawyers. Llewellyn, at the time professor at Columbia, must have thought the message important enough that he arranged for the essay to be simultaneously published both in his home law review and in the American Bar Association's flagship journal.

Llewellyn's essay covers a lot of ground, with about two pages of it dedicated to "the Jurisprudence of advocacy."19 It was important, Llewellyn said, for lawyers to consider judges' personalities as those may affect the outcome of cases. Such a study, he said, should "not ignore the facts of life," which include the possibility that "[i]n the case of a particular judge subject to dyspepsia, the unfortunate effects of a particular ill-advised breakfast do alter the advocate's practical problem. ${ }^{20}$ Such happenstances, as well as ailments of a more permanent nature, he said, are plainly relevant for advocates, and indeed are probably recognized by all of them. He therefore "confess[ed] to total inability to understand why" discussing such matters should be considered "unilluminating or indecent." ${ }^{21}$ Nevertheless, Llewellyn qualified these remarks by saying that he never studied any "judge's breakfast, or headache," and he did not think either "a peculiarly fruitful line of study."22

Though Llewellyn made no reference to any previous scholarship, the apologetic tone of his remarks on the subject suggests that he was responding here to already-existing associations between legal realism and judicial breakfasts. Kennedy had already taken a bite at the realists on these grounds in I932, almost a decade before the publication of Llewellyn's essay. And Clark's remarks, published only a year after Llewellyn's essay, suggest the link was considered in academic circles as matter of common knowledge.

And indeed there is an earlier, and much clearer, discussion of this relationship in an earlier, well-known realist tract. Jerome Frank's blockbuster Law and the Modern Mind was published in I930 and immediately caused a stir. Here was a book written by a practitioner who did away with all the pieties of his profession and presented to the world a thoroughly unvarnished account of the law. To this day the book enjoys a rather notorious reputation, not entirely deserved. Though not without its faults (which Frank later acknowledged), the book is reformist and humanist in spirit, not cynical or nihilist. ${ }^{23}$

One of the many topics the book addresses is the view that legal outcomes are primarily governed by legal rules. Frank did not deny the existence and significance of legal rules to adjudication, but he insisted that they were only part of the story. An important part according to Frank was the personality of the judge. One piece of evidence he relied on was an obscure I869

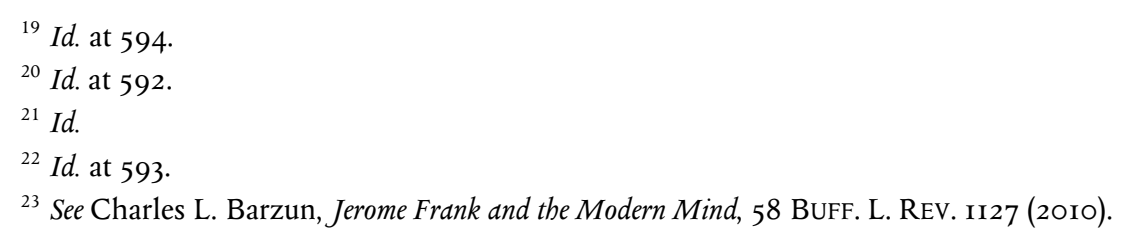


decision by the Alabama Supreme Court. He quoted approvingly (and italicized for extra effect) the court's proclamation that

it cannot safely be denied that mere judicial discretion is sometimes very much interfered with by prejudge, which may be swayed and controlled by the merest trifles such as the toothache, the rheumatism, the gout, or a fit of indigestion, or even through the very means by which indigestion is frequently sought to be avoided. ${ }^{24}$

This then is the smoking gun. Legal realism's single most famous book suggests a clear link between the state's of judge's mind and the state of his digestion. It is not entirely clear why Kennedy chose to cite Llewellyn and not Frank, even though Frank's endorsement of the idea was far more forthright. He definitely knew Law and the Modern Mind and though not a fan, he acknowledged its "lively and attractive style." ${ }^{25}$ It is likely that the fact Frank quoted a case in support of his contention made him a less congenial target. Coming from what even then was an old judicial decision from a state Supreme Court gave the idea the kind of respectability, even authority, that the ramblings of an out-of-touch Ivy League academic could never have.

The decision in this case involved a petition by one John W. Chase, a white man accused of murdering a black man, to have his trial removed from Montgomery County. Chase alleged that due to a concerted effort to vilify him, public opinion in Montgomery and neighboring counties, where black population was substantial, was set against him and for this reason he would not get a fair trial. The specific question the court had to address was the scope of discretion available to the trial court in deciding whether to remove the case. The statute in question said that a defendant "may have his trial removed to another county," and the prosecution argued that this meant the trial court had a wide discretion whether to allow or refuse the motion, which should not be interfered with.

The author of the decision was Justice Thomas Minott Peters (I8IO-I888), who would later serve briefly as Chief Justice of Alabama. He was a man of considerable abilities and achievements, who "distinguished himself as a lawyer, a judge, a state assemblyman, a teacher, a schoolmaster, a newspaper editor, and as a scientist with a national reputation who was elected to the American Scientific Association." ${ }^{26}$ A committed Unionist, Peters argued after the Civil War for

${ }^{24}$ Ex p. Chase, 43 Ala. 303, 3IO-II (1869), quoted in Jerome Frank, LAW AND MOdERn Mind I37 (I930). Frank did not forget this case and quoted from it again in JEROME FrANK, COURTS ON TRIAL: MYTH AND REALITY in AMERICAN Justice 4 I4 (I949) [hereinafter FranK, COURTS ON TRIAL].

${ }^{25}$ Walter B. Kennedy, The Cult of the Robe: A Dissent, I4 Fordham L. ReV. I92, 192 (1945).

${ }^{26}$ Paul Horton, Lightning Rod Scalawag: The Unlikely Political Career of Thomas Minott Peters, 64 ALA. ReV. II6, II9 (2OII). Horton's essay is a valuable, sympathetic portrait of Peters's life and accomplishments. 
the application of the Civil Rights Act of I866 as a challenge to Black Codes, and even successfully defended an interracial marriage from a legal challenge. ${ }^{27}$ After he was elected to the Alabama Supreme Court, Justice Peters issued a series of decisions that affirmed his opposition to the secession and his commitment to the civil rights of newly enfranchised former slaves. ${ }^{28}$

Justice Peters's Chase decision consisted of two steps. He first explained that the right to a trial heard by a "fair and impartial jury" was a fundamental right that could never be infringed. The strength of this right, he argued, affected the scope of the discretion. Peters then argued that the word "may" in the relevant statute should be effectively be read as "must," assuming the facts regarding the impediments to a fair trial are shown to be true.

As something of a rhetorical flourish Justice Peters then considered the dangers of wide discretion. The full passage from which some words have already been quoted reads as follows:

The writer of this opinion has known a popular judicial officer grow quite angry with a suitor in his court, and threaten him with imprisonment, for no ostensible reason, save the fact, that he wore an overcoat made of wolf skins! Moreover, it can not safely be denied, that mere judicial discretion is sometimes very much interfered with by prejudice, which may be swayed and controlled by the merest trifles - such as the tooth ache, the rheumatism, the gout, or a fit of indigestion, or even through the very means by which indigestion is frequently sought to be avoided. ${ }^{29}$

He then added:

Whatever may have been the construction of this important statute heretofore, it is now evidently unwise longer to keep so indispensible [sic] a right as that of "a fair and impartial trial,["] in a criminal case, under the uncertain security of a power, so uncontrollable and liable to error as mere judicial discretion - a power that may possibly be misdirected by a fit of temporary sickness, an extra mint julep, or the smell or looks of a peculiar overcoat, or things more trivial than these, which may imperil the due course of justice in the administration of the law. Trifles, however ridiculous, cease to be trifles when they may interfere with a safe administration of the law. ${ }^{30}$

Discretion, then, was dangerous, especially when acknowledging the un- or semi-conscious ways in our prejudices may affect our decisions.

Frank did not follow this reasoning all the way through. He thought the discretionary element in adjudication is ineliminable and therefore better openly disclosed and discussed than concealed. But it is nevertheless obvious why he picked this case: Frank had a life-long obsession with trials. He thought they were far more important than appellate decisions and that the outcomes of decisions there, because they largely turned on questions of fact, were far less predictable. In his mind, other legal scholars (including most other legal realists) suffered from a malady

\footnotetext{
${ }^{27}$ See id. at 129.

${ }^{28}$ See id. at $133-35$. All this apparently made Peters "one of the most hated jurists in Alabama history." Id. at II6.

${ }^{29}$ Chase, 43 Ala. at 3IO-II.

${ }^{30} \mathrm{Id}$. at $3 \mathrm{II}$.
} 
he called "appellate-court-itis," the excessive focus on appellate courts. ${ }^{31}$ This interest in the trial may explain his willingness to discuss the gastronomical idea more openly than anyone else. Appellate decisions are less often decided on the spot and are typically decided by a multimember panel. These factors reduce the odds that the fleeting discomforts that afflict all of us on occasion will affect the outcome of a given case. The lightning-speed, reasons-free decisions that are part of every trial are much more prone to such influences. ${ }^{32}$

Though Frank is sometimes said to have mellowed in his later years, especially after his appointment to the Second Circuit, his 1949 book, Courts on Trial, retains much of its predecessor's vigor. Frank returned there to the topic of the hidden influences on judicial decision-making and asserted that though "no one, except jocularly, has ever proposed explaining all or most decisions in terms of the judges' digestive disturbances," ${ }^{33}$ such effects could not be ignored. "Out of my experience as a trial lawyer," he wrote, "I can testify that a trial judge, because of overeating at lunch, may be so somnolent in the afternoon court-session that he fails to hear an important item of testimony and so disregards it when deciding the case." 34 To reassure his readers that these were not just the cynical remarks of a famously contrarian lawyer but a long-acknowledged phenomenon, Frank added illustrative quotations from Alexander Pope, Charles Dickens, Lord Campbell, and Michel de Montaigne. That these remarks came mostly from non-lawyers more than suggests that this was not some novel revelation, but something that others have long acknowledged, and that lawyers, perhaps out of their protectiveness to the image of their profession, were keen to hide.

III.

The truth, then, lies somewhere between the realists' defenders and their detractors. The idea that what the judge had for breakfast apparently has quite an old provenance. It was familiar enough that one finds casual references to it in newspapers predating the realists. For example, in I899 a Minnesota newspaper reported on a lecture by the Minnesota pastor Samuel G. Smith in which he reportedly declared that "the administration of justice in the police courts depends largely upon the digestion of the judges." ${ }^{35}$ A decade later, a letter to the editor to the Sunday Oregonian stated that " $[\mathrm{t}]$ he same Judge might, in accordance with the condition of his digestion

\footnotetext{
${ }^{31}$ Jerome Frank, Legal Thinking in Three Dimensions, I SYRACUSE L. REV. 9, 23 (1949). In this essay (published also as the preface for the 1949 edition of Law and the Modern Mind), Frank targeted only Benjamin Cardozo. Elsewhere Frank led a more general charge against what he called "the upper court myth, the myth that upper courts are the heart of court-house government." FRANK, COURTS ON TRIAL, supra note 24, at 222-24.

${ }^{32}$ At times, however, Frank was unwilling to grant even that. See Frank, supra note i6, at 29.

${ }^{33}$ FRANK, COURTS ON TRIAL, supra note 24, at I62.

${ }^{34} I d$.

${ }^{35}$ Slums in Life of Cities, St. PaUl Globe (Nov. I8, I899) at 8, 8.
} 
at the time, rule favorably today and unfavorably tomorrow." ${ }^{36}$ It was a kind of received wisdom among cynical (or perhaps, realistic) observers of the judicial system that personal and psychological factors affected adjudication. And this idea was at times summarized in terms of "what the judge had for breakfast." The authors of an early study on individual differences among judges reported that when they had considered embarking on the study, a colleague tried to dissuade them from pursuing it "since everyone knew that what the judge had for breakfast frequently determined the length or kind of sentence he gave." ${ }^{\text {37 }}$

Perhaps the most prominent person to voice this idea was Charlton T. Lewis (I834-1904). Lewis had a wide-ranging career as a scholar and a lawyer. He wrote a history of Germany, compiled a Latin dictionary, and in the course of his life lectured on a wide range of topics, including math, Greek, and insurance. In addition, he served as counsel for the Mutual Insurance Company, and for a short time was even the managing editor of the New York Evening Post. ${ }^{38}$ Another issue that preoccupied Lewis was prison reform, and late in his life served as president of the New York State Prison Association. In this capacity he gave a lecture entitled "The Principles Underlying the Problems of Crime," which according to a contemporaneous report criticized the wide divergence in punishment in different states, as well as within a single state: "You have but to look at the sentences inflicted by the different judges of this city for similar offences [sic] to see how far [the] administration [of justice] in one State attains its ends. The term of imprisonment which is fixed for a particular convict depends far more upon the temper and digestion of the judge than upon considerations of vital justice." ${ }^{39}$

As we have seen, some of the realists were not averse to the idea and made references to it, explicitly and in print. But there is a further twist to the story, for the attitude toward the judge's indigestion reveals something about an important divide among the legal realists. Elsewhere, I argue that what we now call "legal realism" consisted of two very distinct groups of scholars,

${ }^{36}$ W.V. Lance, letter to the editor, Dilatory Moves in Law: Some Judges' Decision Shown to Be Matters of Digestion, Sunday Oregonian (Portland), (Mar. 7, I909) at Io, Io. Some years later the same newspaper summarized an early empirical study on sentencing, and concluded that "the length of sentences imposed by the same judge over a period of time varied for the same offense, depending, perhaps, upon the judge's digestion and the state of public opinion, but the variance was still greater as between jurists." MORNING OrEGONIAN (Portland), (Oct. $2 \mathrm{I}, \mathrm{I} 932)$ at 8,8 .

${ }^{37}$ Frederick J. Gaudet et al., Individual Differences in the Sentencing Tendencies of Judges, 23 J. AM. INST. CRIM. L. \& CRIMINOLOGY 8II, 8I2 (I933). The conclusion of this early study were that sentencing outcomes are actually "fairly well determined" by factors to which the judge was exposed before becoming a judge. Id. at 814 .

${ }^{38}$ See Charlton T. Lewis Dead, Sun (New York) (May 27, 1904) at 3; C.T. Lewis Dead, N.Y. Tribune (May 27, 1904) at 9; Charlton Thomas Lewis, in OBItUARy ReCORD OF Graduates OF YALE UNIVERsity (5th ser.) 324 (1904), http://mssa.library.yale.edu/obituary_record/I859_1924/1903-04.pdf.

${ }^{39}$ See Justice to Criminals, N.Y. Tribune (July I9, I902) at 5, 5. Cf. Charlton T. Lewis, Annual Report of the Executive Committee, in FifTy-Ninth ANNUAL RePORT OF THE PRISON AsSOCIATION OF NEW YORK. For the YeAR I9O3, at II, I2 (1904) (criticizing the "inequality of sentences arising from differences in the views and disposition of judges"). 
who on a series of issues held very different views. One realist group was realistic in the sense that it wanted to make the university study of law more oriented toward legal practice. It saw the real danger in excessively theoretical study of law, one that did not reflect law as it was found in the real world. The other realist strand wanted to push the academic study of law in the opposite direction, away from legal practice and in the direction of the natural sciences. These legal realists, of whom Felix Cohen, Walter Wheeler Cook, and Hessel Yntema were the most notable, were realistic in the sense that it considered the study of law continuous with scientific realism. ${ }^{40}$ Llewellyn and Frank were the most notable members of the first group, and as such were willing to say that these psychological factors were part of the law, or (if it's any different) part of legal practice. ${ }^{41}$ On the other hand, perhaps because of their resistance to the application of scientific method to the law, they did not seek to examine the matter empirically.

This difference in orientation also manifested itself in the attitude toward uncertainty. Because the practice-oriented realists looked at law from the perspective of the practitioner, they considered the subjective, human element in the law as ineliminable. Instead of ignoring it, or hopelessly trying to eradicate it, they thought lawyers should acknowledge it and to some extent even embrace it as a source of law's vitality. ${ }^{42}$ The idea that judicial decisions were on occasion influenced by the judge's state of digestion fit right into this view, and from that perspective perhaps not necessarily an unmitigated evil. It was a vivid indication that law was a human affair. The other realists, on the other hand, were realistic in seeking to base law on realities as discovered by empirical science. Many of them were attracted to science in part because it held the promise of minimizing the uncertainties that pervaded the law, including those caused by the foibles of human nature. Cohen thus criticized "certain advocates of realistic jurisprudence" for their "willing[ness] to look upon decisions as simple unanalyzable products of judicial hunches or indigestion." "Law," he countered, "is not a mass of unrelated decisions nor a product of judicial bellyaches." With the right scientific methods one can discover that law was grounded in "predictable, social determinants that govern the course of judicial decision." ${ }^{43}$ Despite this difference, it should be emphasized that even among the practice-oriented realists no-one has ever

${ }^{40}$ See Dan Priel, The Return of Legal Realism, in The Oxford HANDBOOK OF HiStORICAL Legal ReSEARCH (Markus D. Dubber \& Christopher Tomlins eds., forthcoming 20I8), available at https://ssrn.com/abstract=2989165; Dan Priel, Legal Realisms (unpublished manuscript).

${ }^{41}$ See Frank, supra note I6, at 31-39; Karl N. Llewellyn, How Appellate Courts Decide Cases (pt. I), I6 PA. B. AsS'N Q. 220, 227 (1945).

${ }^{42}$ See, e.g., FRANK, supra note 24, at 98; Karl N. Llewellyn, Remarks on the Theory of Appellate Decision and the Rules of or Canons about How Statutes Are to Be Construed, 3 VAND. L. REv. 395, 397 (1950). Acknowledgement of this aspect should not be mistaken for the view that judges were free to decide cases any way they wanted. Contrary to prevailing views on the realists, they believed legal doctrine was usually fairly determinate and capable of constraining judges. See Priel, Legal Realisms, supra note 40.

${ }^{43}$ Felix S. Cohen, Transcendental Nonsense and the Functional Approach, 35 Colum. L. Rev. 809, 843 (I935). The underlying idea is that one could turn to social science to discover a predictable pattern of behavior. Such 
suggested that adjudication is primarily determined by judges' passing ailments. And none of the realists, of whatever stripe, ever put the question to any kind of empirical examination.

And so the matter remained for a many years. A recent paper that generated considerable media attention picked up on where the realists left off. The study examined the decisions of an Israeli parole board and found that prisoners whose case was heard early in the morning were more likely to have their petition granted than those whose cases were heard just before lunch. The board became sympathetic again after the lunch break with rates of release declining again afterwards. ${ }^{44}$ The authors of the study considered hunger and tiredness as the most likely explanation for this result. Others, however, questioned that conclusion, suggesting alternative explanations having to do with the impact of legal representation or the possibility that the cases were not heard in random order. ${ }^{45}$

A controlled experimental setting, despite its limitations, might shed some further light on the question. Existing studies already show that hunger and other kinds of physical discomfort have various impacts on cognitive abilities and decision-making, ${ }^{46}$ but as the question here may have to do more with empathy than with cognitive abilities, their relevance to the question at hand is unclear. To test it subjects would be given the task of adjudicating an identical sequence of cases over several hours. The cases would either be based exclusively on written materials or on videotaped "trial(s)" that will ensure that all subjects are given identical evidence, presented in exactly the same way. Subjects will have to decide whether to convict the defendants, and if they convict, to decide on the appropriate punishment. Some of the subjects will be given access to food throughout the process while others kept hungry. For extra flavor, one could further examine whether different kinds of food (sweet versus salty, spicy versus mild) have any effect on decision-making.

Until such a study is undertaken it looks like we remain where Llewellyn was when writing in I940- with a plausible hypothesis, but no decisive answer. As for historians, they may have another question in store. The April and May I9I4 issues of several Christian magazines carried a short advertisement that looks at first like a genuine news report (see Figure I). This early

information could be used to improve society by employing the same scientific methods. Interestingly, like the later scientific legal realists, Charlton Lewis was committed to the application of scientific method to legal reform on the basis of welfarist principles. See The Reform of Penal Law, N.Y. TIMES (May I6, I903) at 5.

${ }^{44}$ See Shai Danziger et al., Extraneous Factors in Judicial Decisions, Io8 Proc. NAT'L ACAD. SCI. 6889 (2011).

${ }^{45}$ See Keren Weinshall-Margel \& John Shapard, Overlooked Factors in the Analysis of Parole Decisions, Io8 Proc. NAT'L ACAD. SCI. E833 (20II); but see Shai Danziger et al., Reply to Weinshall-Margel and Shapard: Extraneous Factors in Judicial Decisions Persist, Io8 Proc. NAT'L ACAD. SCI. E834 (2011).

46 See Roy Y. Baumeister \& John Tierney, Willpower: Rediscovering the Greatest Human Strength 22-23, 225-26 (2OII) (hunger diminishes willpower); Sendhil Mullainathan \& Eldar Shafir, SCARCity: Why Having Too Little Means So Much 5-8 (2013) (extreme hunger affecting interests and cognitive abilities). 
example of native advertising tells of an unnamed member of New York's state Prison Commission who is "reported to have said" in a public address that "[t]he whole system of sentencing is absurd. The length of a man's sentence sometimes depends upon the judge's digestion." ${ }^{47}$ The copywriter did not find this suggestion too alarming. After all, "[j]udges are only human beings," and there is no doubt that a "disordered or impaired digestion" will get in the way of "thinking clearly, fairly, judiciously." ${ }^{48}$ But the ad went on to suggest a more intriguing link between indigestion and crime: "it is a fact that a well-balanced ration, such as shredded wheat biscuit, with fresh fruits, develops an evenness of disposition and a vigor an equilibrium in the bodily functions." (Could this have been the unlikely source for Walter Kennedy's "wheatie-explanation"?) The wrong kind of food, one with "an excess of proteid," can lead to "the accumulation of toxins in the body." Persist with such a diet, and the body will eventually not be able to rid itself of this "poison." The ad remains non-committed on the question whether the "more heinous crimes can be traced to indigestion," ${ }^{49}$ but students of gastro-juridical history may well want to examine whether it was at this moment that the Twinkie defense was born.

${ }^{47}$ Judges and Digestion, 89 Christian Adv. 55I, 55I (I9I4); IO9 ChurChman 5I7, 5 I7 (19I4); 99 CONGREGATIONALIST \& Christian WORLD 538, 538 (I9I4); 45 CONTINENT 52I, 52I (I9I4); 20 ASSEMBly HeRALD 285 , 285 (1914). Thanks to Simon Stern who found and sent me the relevant news report, it is a good estimate that the person in question is Charlton Lewis, discussed in text accompanying notes 38-39, supra. According to the ad the address was recent and took place in Buffalo. Lewis's address was over ten years old at the time, and it was delivered in New York. Other than that, however, the details match.

${ }^{48}$ Judges and Digestion, 89 CHristian ADV. 55I, 55I (I9I4).

${ }^{49} I d$. 
Figure I: One version of the ad mentioned in the text (this one from The Christian Advocate)

\section{JUDGES AND DIGESTION}

\section{A Prominent Prison Reformer Declares that Many Prison Sentences are the Results of Bad Digestions}

A well-known member of the State Prison Commission of New York, in a recent address in Buffalo, is reported to have said: "The whole system of sentencing is absurd. The length of a man's sentence sometimes depends upon the Judge's digestion."

There may be some difference of opinion as to the correctness of this assertion when applied to Judges, but if this prison reformer had gone a little further and declared that many crimes may be traced to bad digestion he would have stated a truth universally recognized and upon which there is little room for controversy. Of course Judges are only human beings and to say that their dispositions are sometimes affected by their digestions is simply another way of affirming the fact that they are humsn. No man who has disordered or impaired digestion is eapable of thinking clearly, fairly, judiciously.

So far as erimes are concerned, it would not be possible to compile statisties showing the intimate relation between crime and indigestion. Indigestion disturbs mental equilibrium, poisons the blood and leads to acts which could never be committed by a man whose digestive powers are in good working order. A quarrelsome temperament is aggravated and quite often derelojed by an excess of high proteid foods.

Whether the more heinous crimes can be traced to indigestion or not, it is a fact that a well-balanced rution, such as shredded wheat biscuit, with fresh fruits, develops an evenness of disjosition and a vigor and equilib rium in the bodily functions that brings not ouly the greatest happiness, but the highest working effiriency. No man can work well or think well if his mind is embittered by prejudices and resentments that come from disordered digestion. Where there is an excess of proteid in the diet there is an accumulation of toxins in the body, and if this diet be persisted in there comes a time when the eliminating functions of the body refuse to throw off the poison.

In shredded wheat biscuit you have all the tissne-building elements needed by the body, prepared in such a form as to be easily and quickly digested, not only supplying nutrition to every part of the body, but keeping the bowels healthy and active. Two shredded wheat bircuits, with hot milk and a little cream, will supply all the nourisbment needed for a half day's work, costs much less than ment or any other high-proteid food and will keep mind and body in top-noteh working condition.-Advt. 